\title{
LC-MS/MS screening method for designer amphetamines, tryptamines, and piperazines in serum
}

\author{
Ariane Wohlfarth • Wolfgang Weinmann • \\ Sebastian Dresen
}

Received: 30 September 2009 /Revised: 8 December 2009 /Accepted: 9 December 2009 / Published online: 13 January 2010

(C) Springer-Verlag 2010

\begin{abstract}
Since the late 1990s and early 2000s, derivatives of well-known designer drugs as well as new psychoactive compounds have been sold on the illicit drug market and have led to intoxications and fatalities. The LC-MS/MS screening method presented covers 31 new designer drugs as well as cathinone, methcathinone, phencyclidine, and ketamine which were included to complete the screening spectrum. All but the last two are modified molecular structures of amphetamine, tryptamine, or piperazine. Among the amphetamine derivatives are cathinone, methcathinone, 3,4-DMA, 2,5-DMA, DOB, DOET, DOM, ethylamphetamine, MDDMA, 4-MTA, PMA, PMMA, 3,4,5-TMA, TMA- 6 and members of the $2 \mathrm{C}$ group: $2 \mathrm{C}$ B, 2C-D, 2C-H, 2C-I, 2C-P, 2C-T-2, 2C-T-4, and 2C-T-7. AMT, DPT, DiPT, MiPT, DMT, and 5MeO-DMT are contained in the tryptamine group, BZP, MDBP, TFMPP, $\mathrm{mCPP}$, and MeOPP in the piperazine group. Using an Applied Biosystems LC-MS/MS API 365 TurboIonSpray it is possible to identify all 35 substances. After addition of internal standards and mixed-mode solid-phase extraction the analytes are separated using a Synergi Polar RP column and gradient elution with $1 \mathrm{mM}$ ammonium formate and methanol/ $0.1 \%$ formic acid as mobile phases A and B. Data acquisition is performed in MRM mode with positive electro spray ionization. The assay is selective for all tested substances. Limits of detection were determined by analyzing $S / N$-ratios and are between
\end{abstract}

Parts of this work were presented at the 47th Conference of TIAFT 2009 in Geneva.

A. Wohlfarth $(\bowtie) \cdot$ W. Weinmann $\cdot S$. Dresen

Institute of Forensic Medicine,

University Medical Centre Freiburg,

Albertstraße 9,

79104 Freiburg, Germany

e-mail: ariane.wohlfarth@uniklinik-freiburg.de
1.0 and $5.0 \mathrm{ng} / \mathrm{mL}$. Matrix effects lie between $65 \%$ and $118 \%$, extraction efficiencies range from $72 \%$ to $90 \%$.

Keywords Designer drugs · LC-MS/MS · Screening · Drugs of abuse

\section{Introduction}

The term designer drugs stands for either synthetically changed natural substances or completely designed molecular structures that have psychotropic effects. Long known and relatively widely used designer drugs are amphetamine, methamphetamine, MDMA, MDEA, MDA, and MBDB which can be regarded as the classical representatives and are under control of international laws for a long time.

It is in the nature of these laws which are to ban psychotropic substances to provoke the synthesis of new derivatives. To bypass illegality, minor changes of common molecular structures are sufficient - at least for some time. Besides, basic structures are modified in order to optimize effects. Since the late 1990s and early 2000s, modifications of "classical" designer drugs have been sold as recreational drugs or "research chemicals" on the black market.

As far as there is a demand, a continuing search and introduction of new synthetic substances is to be assumed.

According to the World Drug Report 2008 of the United Nations [1] the abuse of "other drugs", including substances such as methaqualone, khat, LSD, ketamine, and various new designer drugs, account for $3 \%$ of all drug seizure cases. The situation in Germany is comparable as the abuse remains on a very low level [2]. Nevertheless, there have been several reports about intoxications and fatal cases associated with the consumption of new designer drugs [3-12]. For diagnosis of such poisonings, an 
analytical method for detection and quantification is therefore required in clinical and forensic toxicology.

The substances that belong to "new designer drugs" can be divided in five structural subgroups: phenylalkylamines (mainly amphetamines), tryptamines, piperazines, pyrrolidinophenone, and phenylcyclohexyl derivates.

In the last years, several screening and validated quantification methods using different techniques have been developed and published. However, generally, the focus lies on one compound class or concentrates on a mix of frequently used substances. For analysis of new designer amphetamines, procedures were published using capillary electrophoresismass spectrometry (CE-MS) for 2,5-methylendioxyamphetamines [13], the 2C-T-series [14], the ALEPH-series [15], and 4-alkyl-2,5-dimethoxyamphetamines [16], using capillary electrophoresis coupled with a diode array detector (CE-DAD) for dimethoxyamphetamines [17] and liquid chromatography-mass spectrometry (LC-MS) for the TMA-series [18]. One method that mainly includes piperzines [19] and one for seven analytes of the $2 \mathrm{C}$ series [30] use gas chromatography-mass spectrometry (GC-MS).

For analysis of mixtures GC-MS, LC-MS, and LC-MS/ MS procedures have been published, containing a composition of about six to ten new designer drugs from different subgroups [20-23]. One GC-MS method for urine analysis covered 16 substances [24].

As none of the above-mentioned methods going beyond a limited number of analytes are applicable for serum or covers more than one class, it was our intention to establish an extensive LC-MS/MS screening method covering the maximum number of available substances from all subgroups which can be detected in one run.

The LC-MS/MS screening method presented now includes 31 new designer drugs that could be purchased as reference standards or were provided by the Landeskriminalamt Hamburg. These substances are modified molecular structures of amphetamine, tryptamine, and piperazine. Pyrrolidinophenone or phenylcyclohexyl derivates were not commercially available yet.

Cathinone and methcathinone which in fact are amphetamine-like natural products as well as phencyclidine and ketamine which have hallucinogenic effects were included in the method because they also could be interesting for designer drug consumers. Abbreviations are explained in Table 1, an overview of substance classes and all new designer drugs included in the method is given in Fig. 1.

\section{Materials and methods}

Chemicals and reagents

Methanolic solutions of 2,5-DMA, 2C-B, 2C-H, 2C-I, 2CT-2，2C-T-4，2C-T-7，3,4,5-TMA，3,4-DMA，4-MTA, benzylpiperazine, cathinone, DMT, DOB, DOET, DOM, mCPP, MDDMA, methcathinone, $N$-ethylamphetamine, phencyclidine, PMA, and PMMA as well as the internal standards $d 5$-amphetamine, $d 5$-MDMA, $d 5$-MDEA, and d3-cocaine were obtained from Lipomed (Bad Säckingen, Germany). MDBP, MeOPP, and DMPP were purchased from Alfa Aesar (Karlsruhe, Germany). Methanolic solutions of ketamine and of the internal standards $d 10$ fenfluramine, $d 5$-phencyclidine, and $d 4$-ketamine were obtained from LGC Standards (Wesel, Germany). 2C-D, 2C-P, 5MeO-DMT, AMT, DiPT, DPT, MiPT, TFMPP, and TMA-6 were kind gifts from the Landeskriminalamt Hamburg, Germany.

Methanol (HPLC grade) was obtained from J.T. Baker (Deventer, The Netherlands), dichloromethane and formic acid (both analytical grade) from Roth (Karlsruhe, Germany), ammonia ( $>25 \%)$, potassium dihydrogen phosphate, and acetic acid (analytical grade) from Merck (Darmstadt, Germany). Propan-2-ol (p.a.) was obtained from VWR Prolabo (Briare, France) and ammonium formate from Sigma-Aldrich (Steinheim, Germany).

Chromabond Drug cartridges $(200 \mathrm{mg} ; 3 \mathrm{~mL}$ ) for solidphase extraction were purchased from Macherey-Nagel (Düren, Germany).

Preparation of stock solutions, working solutions, calibration standards, and quality control samples

Stock solutions $(1.0 \mathrm{mg} / \mathrm{mL})$ of solid reference standards were prepared using methanol as solvent and stored at $-20{ }^{\circ} \mathrm{C}$. Stock solutions were then diluted with methanol to obtain appropriate working concentrations $(10 \mu \mathrm{g} / \mathrm{mL}$, $1 \mu \mathrm{g} / \mathrm{mL}$, and $100 \mathrm{ng} / \mathrm{mL}$ ). Moreover, a mixture of the 35 analytes in methanol was prepared at the same concentration levels as the working solutions to facilitate the spiking of samples later.

The internal standard solution contained $10 \mu \mathrm{g} / \mathrm{mL}$ of $d 10$-fenfluramine and $d 5$-phencyclidine, and $5 \mu \mathrm{g} / \mathrm{mL}$ of $d 5$-amphetamine, $d 5$-MDMA, $d 5$-MDEA, $d 4$-ketamine, $d 3$ cocaine, and dimethylphenylpiperazine, respectively.

Human blank plasma from drug free volunteers served as matrix for standards and was spiked with the mixture of the 35 analytes.

Extraction procedure

Plasma samples $(1 \mathrm{~mL})$ were spiked with $20 \mu \mathrm{L}$ of internal standard solution. The samples were then diluted with phosphate buffer ( $\mathrm{pH}$ 6), mixed on a rotary shaker and loaded on solid-phase cartridges (Chromabond Drug) previously conditioned with methanol and adjusted with phosphate buffer at $\mathrm{pH}$ 6. Solid-phase extraction was carried out on a Gilson GX-274 Aspec (Middleton, USA). 
Table 1 Abbreviations

\begin{tabular}{|c|c|}
\hline 2,5-DMA & 1-(2,5-dimethoxyphenyl)propan-2-amine \\
\hline $2 \mathrm{C}-\mathrm{B}$ & 2-(4-bromo-2,5-dimethoxyphenyl)ethanamine \\
\hline $2 \mathrm{C}-\mathrm{D}$ & 2-(2,5-dimethoxy-4-methylphenyl)ethanamine \\
\hline $2 \mathrm{C}-\mathrm{H}$ & 2-(2,5-dimethoxyphenyl)ethanamine \\
\hline $2 \mathrm{C}-\mathrm{I}$ & 2-(4-iodo-2,5-dimethoxyphenyl)ethanamine \\
\hline $2 \mathrm{C}-\mathrm{P}$ & 2-(2,5-dimethoxy-4-propylphenyl)ethanamine \\
\hline $2 \mathrm{C}-\mathrm{T}-2$ & 2-[4-(ethylthio)-2,5-dimethoxyphenyl]ethanamine \\
\hline $2 \mathrm{C}-\mathrm{T}-4$ & 2-[4-(isopropylthio)-2,5-dimethoxyphenyl]ethanamine \\
\hline $2 \mathrm{C}-\mathrm{T}-7$ & 2-[2,5-dimethoxy-4-(propylthio)phenyl]ethanamine \\
\hline $3,4,5-\mathrm{TMA}$ & 1-(3,4,5-trimethoxyphenyl)propan-2-amine \\
\hline 3,4-DMA & 1-(3,4-dimethoxyphenyl)propan-2-amine \\
\hline 4-MTA & 1-[4-(methylthio)phenyl]propan-2-amine \\
\hline $5 \mathrm{MeO}-\mathrm{DMT}$ & 2-(1H-indol-5-methoxy-3-yl)- $N, N$-dimethylethanamine \\
\hline AMT & 1-(1H-indol-3-yl)propan-2-amine \\
\hline $\mathrm{BZP}$ & 1-benzylpiperazine \\
\hline DiPT & 2-(1H-indol-3-yl)- $N, N$-diisopropylethanamine \\
\hline DMPP (IS) & 1-(3,4-dimethylphenyl)piperazine \\
\hline DMT & 2-(1H-indol-3-yl)- $N, N$-dimethylethanamine \\
\hline DOB & 1-(4-bromo-2,5-dimethoxyphenyl)propan-2-amine \\
\hline DOET & 1-(4-ethyl-2,5-dimethoxyphenyl)propan-2-amine \\
\hline DOM & 1-(2,5-dimethoxy-4-methylphenyl)propan-2-amine \\
\hline DPT & 2-(1H-indol-3-yl)- $N, N$-dipropylethanamine \\
\hline Ethylamphetamine & $N$-ethyl-1-phenylpropan-2-amine \\
\hline $\mathrm{mCPP}$ & 1-(3-chlorophenyl)piperazine \\
\hline MDBP & 1-(1,3-benzodioxol-5-ylmethyl)piperazine \\
\hline MDDMA & 1-(1,3-benzodioxol-5-yl)- $N, N$-dimethylpropan-2-amine \\
\hline MeOPP & 1-(4-methoxyphenyl)piperazine \\
\hline MiPT & 2-(1H-indol-3-yl)- $N$-isopropyl, $N$-methylethanamine \\
\hline PMA & 1-(4-methoxyphenyl)propan-2-amine \\
\hline PMMA & 1-(4-methoxyphenyl)- $N$-methylpropan-2-amine \\
\hline TFMPP & 1-[3-(trifluoromethyl)phenyl]piperazine \\
\hline TMA-6 & 1-(2,4,6-trimethoxyphenyl)propan-2-amine \\
\hline
\end{tabular}

After three washing steps (water, $1 \mathrm{~mL}$, flow rate $2 \mathrm{~mL} /$ min; acetic acid, $1 \mathrm{~mL}$, flow rate $2 \mathrm{~mL} / \mathrm{min}$; methanol, $1 \mathrm{~mL}$, flow rate $2 \mathrm{~mL} / \mathrm{min}$ ) the analytes were eluted with $1.5 \mathrm{~mL}$ of dichloromethane/isopropanol $/ 25 \%$ ammonia $(80: 20: 2 ; v / v / v)$. The eluate was evaporated under a gentle stream of nitrogen at $30{ }^{\circ} \mathrm{C}$. During this evaporation step, a mixture of concentrated hydrochloric acid and 2-propanol $(3: 1, v / v)$ was added to prevent the volatile amphetamines from vanishing. When dry, the residue was redissolved in $60 \mu \mathrm{L}$ mobile phase and $20 \mu \mathrm{L}$ was injected in the LC-MS/ MS system.

\section{Apparatus}

The LC system consisted of three Shimadzu AD 10 VP pumps including a degasser (ERC-3415 $\alpha$ ), column oven (Shimadzu CTO-10 AC) which was set at $40{ }^{\circ} \mathrm{C}$ and $\mathrm{CTC}$
PAL autosampler and was controlled by a Shimadzu SCL10A VP. The chromatographic column was a Synergi Polar RP column $(150 \mathrm{~mm} \times 2 \mathrm{~mm}$ internal diameter, $4 \mu \mathrm{m}$, Phenomenex) with a corresponding guard column (Polar RP $4 \mathrm{~mm} \times 2.0 \mathrm{~mm}$ ) which was kept on a constant temperature of $40{ }^{\circ} \mathrm{C}$.

As a detector, a Sciex API 365 tandem mass spectrometer was used. It was equipped with an atmospheric pressure electrospray ionization interface (Turboionspray ${ }^{\circledR}$ ) and run with Analyst software (version 1.3.1).

\section{LC and MS conditions}

The analytes were separated by gradient elution at a flow rate of $0.25 \mathrm{~mL} / \mathrm{min}$, using $1 \mathrm{mM}$ ammonium formate $/ 0.1 \%$ formic acid as mobile phase $\mathrm{A}$ and methanol $/ 0.1 \%$ formic acid as mobile phase B. Before use, the LC system was 


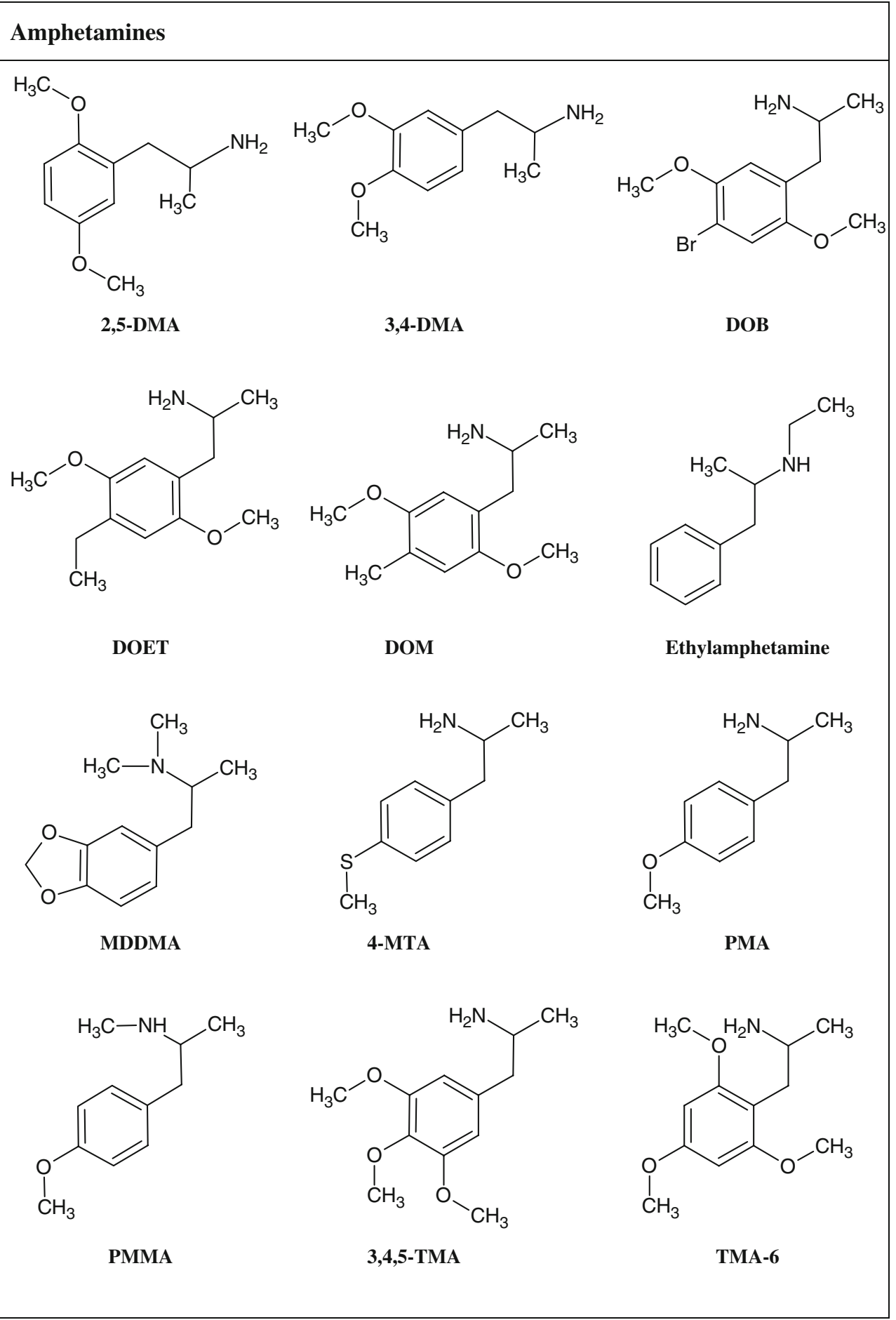

Fig. 1 Classes of designer drugs and their chemical structures

equilibrated with a mixture of $90 \%$ mobile phase $\mathrm{A}$ and $10 \%$ mobile phase $\mathrm{B}$. The gradient was as follows: from the beginning the percentage of the organic phase B increased continuously and reached $100 \%$ after $10 \mathrm{~min}$. After that, the column was cleaned with $100 \%$ mobile phase B for $3 \mathrm{~min}$. Reequilibration with $10 \% \mathrm{~B}$ took $2 \mathrm{~min}$. Isopropanol was added post-column with a constant flow rate of $0.2 \mathrm{~mL} / \mathrm{min}$.
During use, the mobile phases were degassed by the integrated degasser.

Data acquisition was performed in MRM mode with positive electrospray ionization.

The ESI inlet conditions were as follows: nebulizer gas, nitrogen (10); curtain gas, nitrogen (11); ion spray voltage, $5,250 \mathrm{~V}$; ion source temperature, $400{ }^{\circ} \mathrm{C}$. 


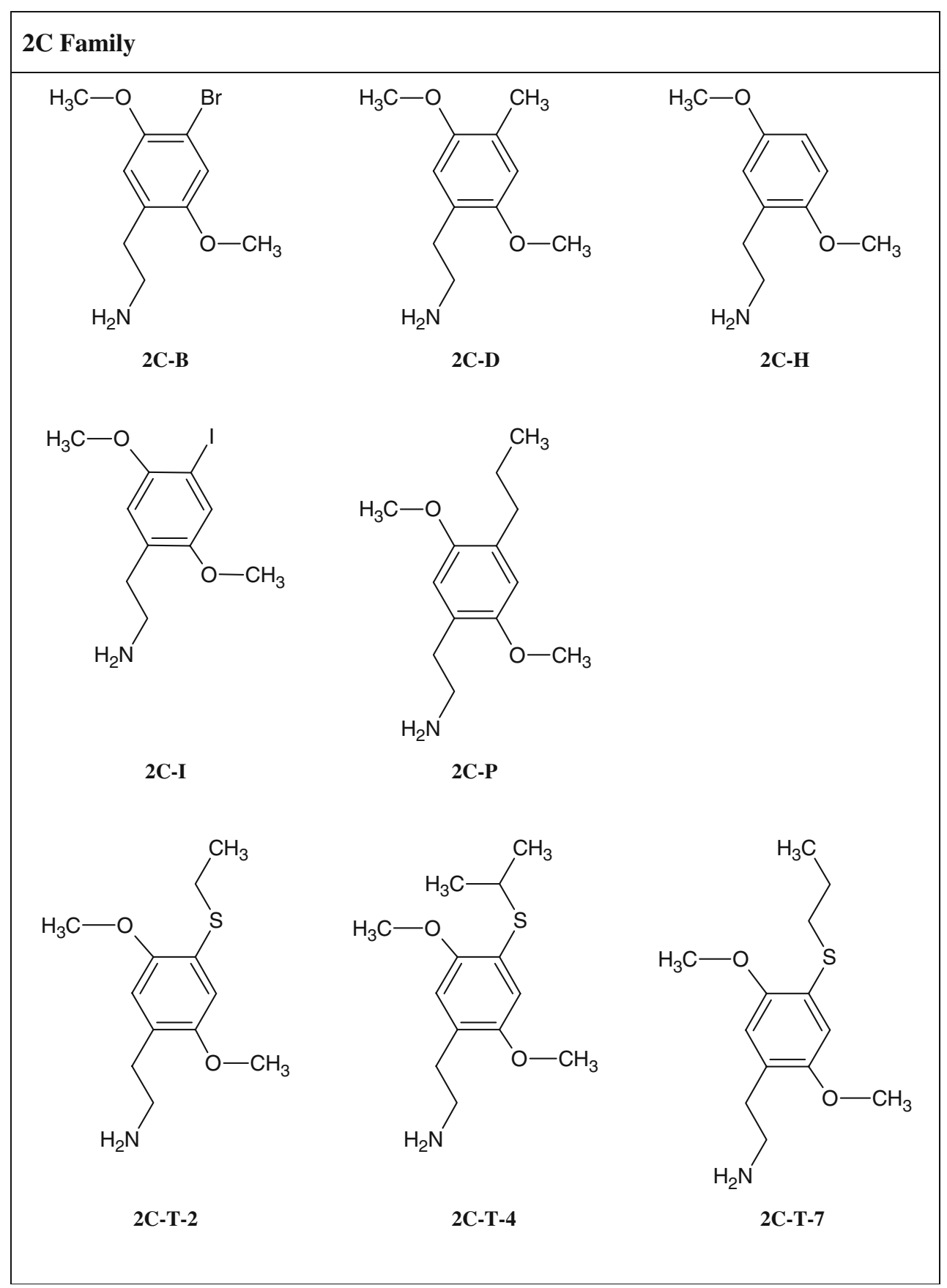

Fig. 1 (continued)

The MS setting was as follows: declustering potential, $10 \mathrm{~V}$; focusing potential, $230 \mathrm{~V}$; entrance potential, $10 \mathrm{~V}$; collision gas, nitrogen $\left(2.8 \times 10^{-5}\right.$ torr $)$; collision cell exit potential, $15 \mathrm{~V}$.

\section{Proof of selectivity}

In selectivity experiments, plasma samples from different persons were checked for interfering peaks in MRM tran- sitions of analytes as well as internal standards. Furthermore, two zero samples that were only spiked with internal standard solution were tested for undeuterated traces of deuterated substances that might pretend the presence of analytes.

Analytes themselves can also show interfering signals in MRM transitions which might pretend the presence of other analytes or wrongly increase their quantity. That is why we monitored single analyte solutions of $1 \mu \mathrm{g} / \mathrm{ml}$ for additional peaks. 


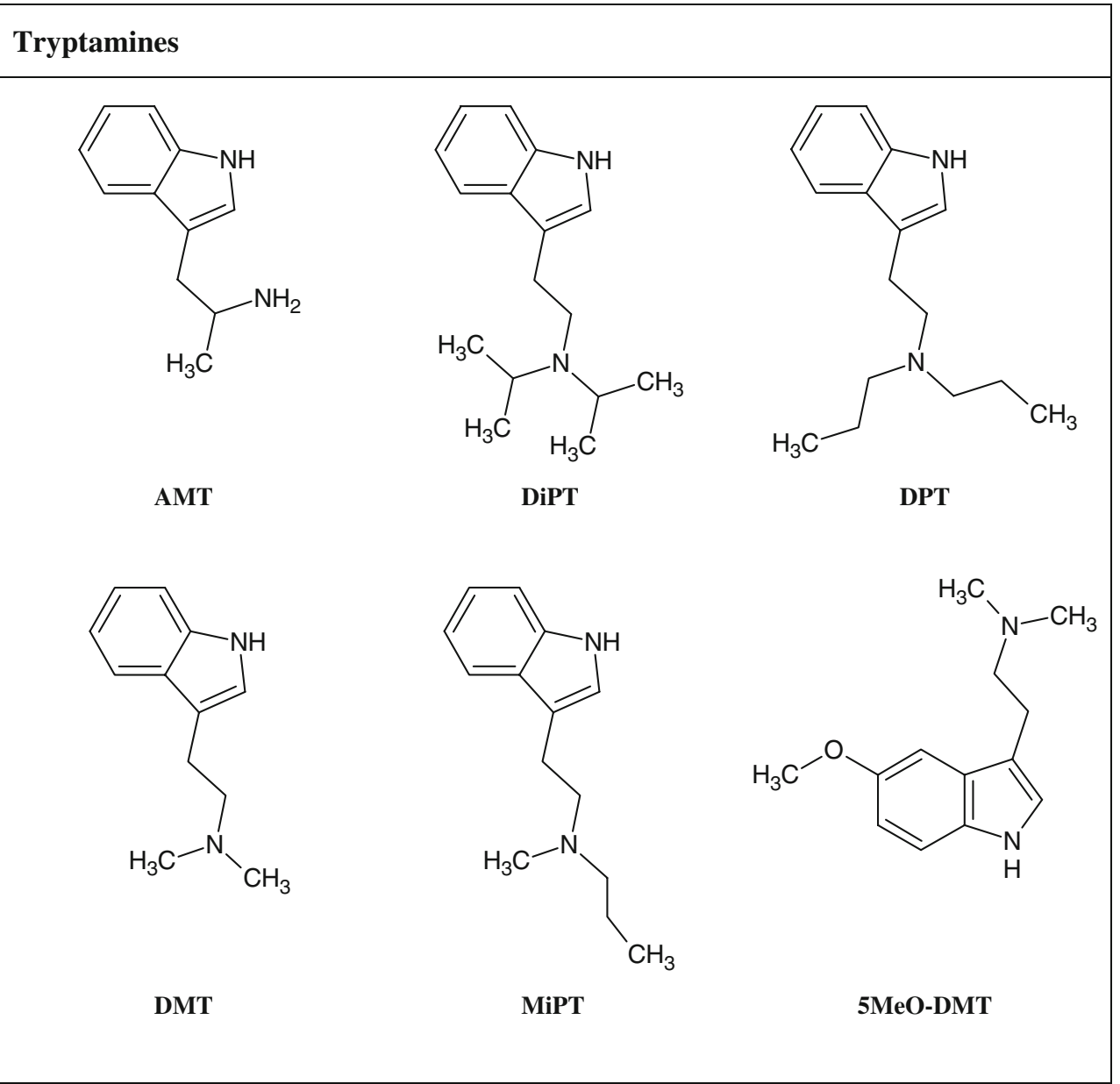

Fig. 1 (continued)

\section{Limits of detection}

According to the validation guideline of the German Society of Toxicological and Forensic Chemistry for calculation of limits of detection (LOD) blank plasma samples of the local blood bank $(1 \mathrm{~mL})$ were spiked with working solutions to obtain calibration standards with concentrations of $1.0,2.5,5.0,7.5$, and $10.0 \mathrm{ng} / \mathrm{mL}$. They were worked up and analyzed as described above.

Six neat samples with $50 \mathrm{ng}$ of all analytes in mobile phase served for determination of relative ion intensities.

\section{Extraction efficiencies and matrix effects}

As proposed by Matuszewski et al. [25], extraction efficiencies and matrix effects were calculated using three different sets of samples.

Bearing in mind that the highest limit of detection was $10 \mathrm{ng} / \mathrm{mL}$, we decided to work with a concentration of $50 \mathrm{ng} / \mathrm{mL}$ to certainly achieve a signal-noise-ratio greater than 10 and exceed the limit of quantification.
The samples of Set 1 consisted of neat standards containing the analytes. Fifty microliters of the designer drug mixture $(c=1 \mu \mathrm{g} / \mathrm{mL}), 20 \mu \mathrm{l}$ of internal standard solution, and $100 \mu 1$ of hydrochloric acid/2-propanol (1:3, $v / v)$ were mixed and evaporated to dryness. The residue was redissolved in $60 \mu \mathrm{L}$ mobile phase.

For preparation of Set 2 blank plasma samples from five volunteers $(1 \mathrm{~mL}$, each) plus $70 \mu \mathrm{l}$ of methanol were extracted by the above-mentioned solid-phase extraction method. After that, the eluate was spiked with $50 \mu \mathrm{L}$ of the same designer drug mixture and $20 \mu \mathrm{l}$ of internal standard solution and was evaporated. Before the residue was completely dry, $100 \mu 1$ of hydrochloric acid/2-propanol were added to prevent the amphetamines from volatilizing. Again, the dry residue was reconstituted in $60 \mu 1$ mobile phase.

Samples of Set 3 were prepared like usual quality control samples. Blank plasma samples from the same five volunteers as for Set 2 were spiked with $50 \mu \mathrm{L}$ designer drug mix and $20 \mu \mathrm{L}$ of internal standard mix. Solid-phase extraction followed. The eluate was then evaporated to dryness (again by using the organic hydrochloric acid mixture) and redissolved in mobile phase. 

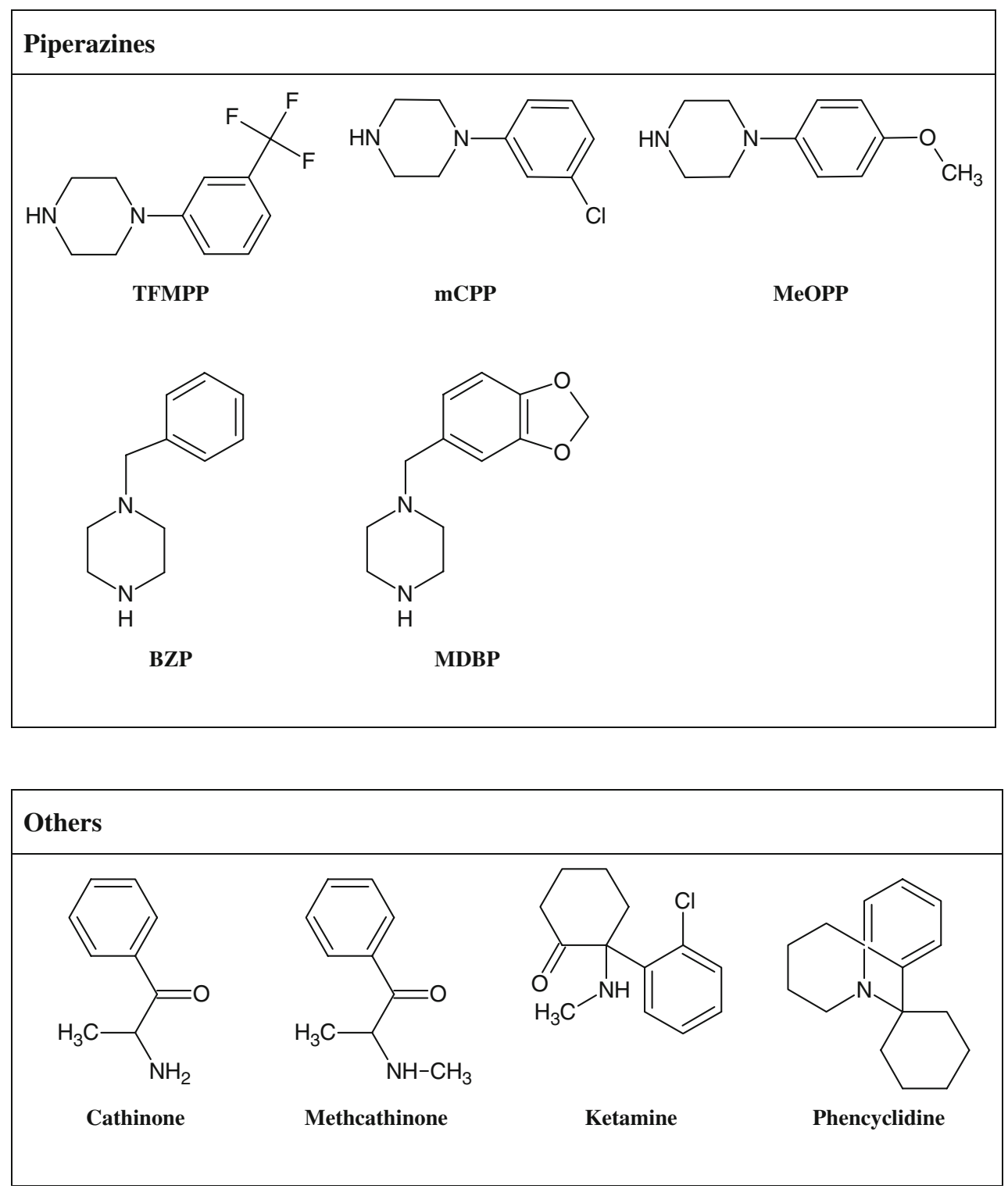

Fig. 1 (continued)

Matrix effects can be estimated by comparison of the peak areas of Set 1 and Set 2. Extraction efficiencies are calculated by comparison of the peak areas of Set 2 and 3 . Mean values and standard deviations of matrix effects as well as extraction efficiencies are reported in percentage and are listed in Table 2.

\section{Results and discussion}

A screening method was developed for selective detection of 31 new designer drugs containing amphetamine, tryptamine, and piperazine structures in human plasma.

In the course of method development, the evaporation turned out to be the weak point of the extraction process. It is well-known that amphetamine volatilizes rapidly during evaporation, some amphetamine derivatives happened to act likewise. To limit the evaporation of analytes, the evaporation process the addition of hydrochloric acid in organic solvent, such as isopropanol, prior to evaporation of the extracts was applied.

In the beginning, product ion scans at collision energies of 20,35 , and $50 \mathrm{eV}$ using a $10 \mu \mathrm{g} / \mathrm{mL}$ standard solution of each analyte in methanol were carried out to determine the most intense fragments. Three spectra of each analyte have been collected and were added in our LC-MS/MS library data base as described in [26] along with their compound names, CAS numbers, formulas, and molecular weights. Finally, two or three MRM transitions were chosen which were not further optimized. 
One transition is monitored for the internal standards whereas the majority of drugs is detected by using two MRM transitions. In cases of isobaric compounds three MRM transitions are used. Often, these substances show nearly the same MS/MS spectra. If no alternative, sufficiently intensive transitions existed identical transitions had to be monitored. Consequently, retention time and relative ion intensities definitely have to be considered for identification.

Substances with identical precursor masses in Q1 are:

$$
\begin{array}{ll}
- & \text { 4-MTA and 2C-H, } m / z 182 \\
- & \text { 2,5-DMA, 2C-D and 3,4-DMA, } m / z 196 \\
- & \text { 2C-P and DOET, } m / z 224
\end{array}
$$

\section{- 3,4,5-TMA and TMA-6, $m / z 226$ \\ - DiPT and DPT, $m / z 245$ \\ - 2C-T-4 and 2C-T-7, $\mathrm{m} / \mathrm{z} 256$}

To obtain acceptable cycle times, the general dwell time for the analytes was set at 15 and $20 \mathrm{~ms}$ for internal standards. To improve intensity or peak shape, the dwell time was extended to $40 \mathrm{~ms}$ for benzylpiperazine, MDBP, phencyclidine, cathinone, and methcathinone. Eventually, the method includes 91 transitions and has a cycle time of $2.17 \mathrm{~s}$.

As can be seen in Fig. 2, some very similar substances (2C-T-4/2C-T-7, DiPT/DPT as well as 2C-P/DOET) could not be completely baseline separated. Nevertheless, they are
Table 2 Extraction efficiency

\begin{tabular}{|c|c|c|c|}
\hline No & Substance name & Extraction efficiency $($ mean $\pm \mathrm{SD}, \%)$ & Matrix effect $($ mean $\pm \mathrm{SD}, \%)$ \\
\hline 1 & Cathinone & $83 \pm 17.3$ & $99 \pm 3.1$ \\
\hline 2 & Ethylamphetamine & $74 \pm 16.3$ & $99 \pm 10.1$ \\
\hline 3 & Methcathinone & $81 \pm 18.3$ & $84 \pm 6.1$ \\
\hline 4 & PMA & $80 \pm 17.7$ & $118 \pm 6.8$ \\
\hline 5 & AMT & $79 \pm 19.2$ & $103 \pm 5.3$ \\
\hline 6 & BZP & $72 \pm 22.0$ & $65 \pm 9.3$ \\
\hline 7 & PMMA & $84 \pm 12.6$ & $91 \pm 3.6$ \\
\hline 8 & $2 \mathrm{C}-\mathrm{H}$ & $79 \pm 13.4$ & $97 \pm 6.1$ \\
\hline 9 & 4-MTA & $84 \pm 19.8$ & $98 \pm 18.0$ \\
\hline 10 & DMT & $81 \pm 12.7$ & $83 \pm 19.4$ \\
\hline 11 & MeOPP & $90 \pm 27.5$ & $85 \pm 15.3$ \\
\hline 12 & 2,5-DMA & $86 \pm 13.7$ & $100 \pm 7.2$ \\
\hline 13 & $2 \mathrm{C}-\mathrm{D}$ & $80 \pm 16.8$ & $99 \pm 6.3$ \\
\hline 14 & 3,4-DMA & $84 \pm 10.1$ & $98 \pm 5.9$ \\
\hline 15 & $\mathrm{mCPP}$ & $77 \pm 17.0$ & $93 \pm 7.3$ \\
\hline 16 & MDDMA & $76 \pm 11.5$ & $92 \pm 2.5$ \\
\hline 17 & DOM & $75 \pm 24.7$ & $106 \pm 8.5$ \\
\hline 18 & $\mathrm{MiPT}$ & $77 \pm 9.4$ & $100 \pm 5.9$ \\
\hline 19 & $5 \mathrm{MeO}-\mathrm{DMT}$ & $79 \pm 7.3$ & $105 \pm 9.6$ \\
\hline 20 & MDBP & $76 \pm 16.4 *$ & $67 \pm 17.8$ \\
\hline 21 & $2 \mathrm{C}-\mathrm{P}$ & $73 \pm 14.0$ & $98 \pm 2.9$ \\
\hline 22 & DOET & $81 \pm 18.3$ & $93 \pm 6.7$ \\
\hline 23 & 3,4,5-TMA & $76 \pm 23.1$ & $106 \pm 11.4$ \\
\hline 24 & TMA- 6 & $79 \pm 15.0$ & $110 \pm 11.7$ \\
\hline 25 & TFMPP & $78 \pm 25.7$ & $98 \pm 6,8$ \\
\hline 26 & ketamine & $89 \pm 18.7$ & $85 \pm 7.3$ \\
\hline 27 & $2 \mathrm{C}-\mathrm{T}-2$ & $79 \pm 14.2$ & $106 \pm 8.0$ \\
\hline 28 & phencyclidine & $72 \pm 14.5$ & $90 \pm 5.7$ \\
\hline 29 & DiPT & $82 \pm 13.0$ & $94 \pm 2.6$ \\
\hline 30 & DPT & $78 \pm 19.6$ & $99 \pm 7.4$ \\
\hline 31 & $2 \mathrm{C}-\mathrm{T}-4$ & $74 \pm 24.8$ & $107 \pm 5.0$ \\
\hline 32 & $2 \mathrm{C}-\mathrm{T}-7$ & $72 \pm 17.3$ & $102 \pm 7.8$ \\
\hline 33 & $2 \mathrm{C}-\mathrm{B}$ & $79 \pm 19.2$ & $99 \pm 7,4$ \\
\hline 34 & DOB & $86 \pm 16.9$ & $93 \pm 2.4$ \\
\hline 35 & $2 \mathrm{C}-\mathrm{I}$ & $76 \pm 14.1$ & $102 \pm 3.6$ \\
\hline
\end{tabular}
and matrix effect for the studied analytes 
distinguishable without difficulty by their different retention times and different relative ion intensities.

The inclusion of internal standards covering the whole runtime and compound classes is very helpful to evaluate retention times when they tend to vary. Comparing retention times of analyte and its corresponding internal standard compensates time shifts.

An overview about the selected transitions of the analytes as well as their corresponding collision energies, retention times, and relative ion intensities is given in Table 3. Product ion scan spectra which were recorded during development are published on the website of ChemicalSoft [27].

The method was found to be selective for all tested analytes. Selectivity experiments with nine different plasma samples revealed neither interferences of matrix compounds, metabolites, or impurities nor undeuterated traces in deuterated internal standards.

Analytes themselves did not show any interfering signals.

As criteria of identification, a signal-to-noise-ratio of greater than or equal to 3 in at least two transitions was set according to international accepted recommendations.
Furthermore, relative ion intensities had to be within the given limits in the EU guideline 2002/657 [28]. According to this guideline, the allowed deviations of relative ion intensities are as follows:

- $\quad$ Relative ion intensity (in percent) of the first qualifier under 10\%: $\pm 50 \%$

- $\quad$ Relative ion intensity (in \%) of the first qualifier 10 $20 \%: \pm 30 \%$

- $\quad$ Relative ion intensity (in \%) of the first qualifier 20 $50 \%: \pm 25 \%$

- $\quad$ Relative ion intensity (in \%) of the first qualifier more than $50 \%$ : $\pm 20 \%$

At the given limits of detection, all the analytes fulfilled these criteria.

Limits of detection were between 1.0 and $5.0 \mathrm{ng} / \mathrm{mL}$ and are listed in Table 3 with the signal-to-noise-ratios of the quantifier and the first qualifier.

As there is only little experience with new designer drugs, data on "therapeutic" and toxic serum concentrations is rare. For some substances, first hints are given by case reports already published: in fatal cases, plasma concentrations for BZP were $0.71,<0.50$, and $1.39 \mathrm{mg} / \mathrm{L}$, for

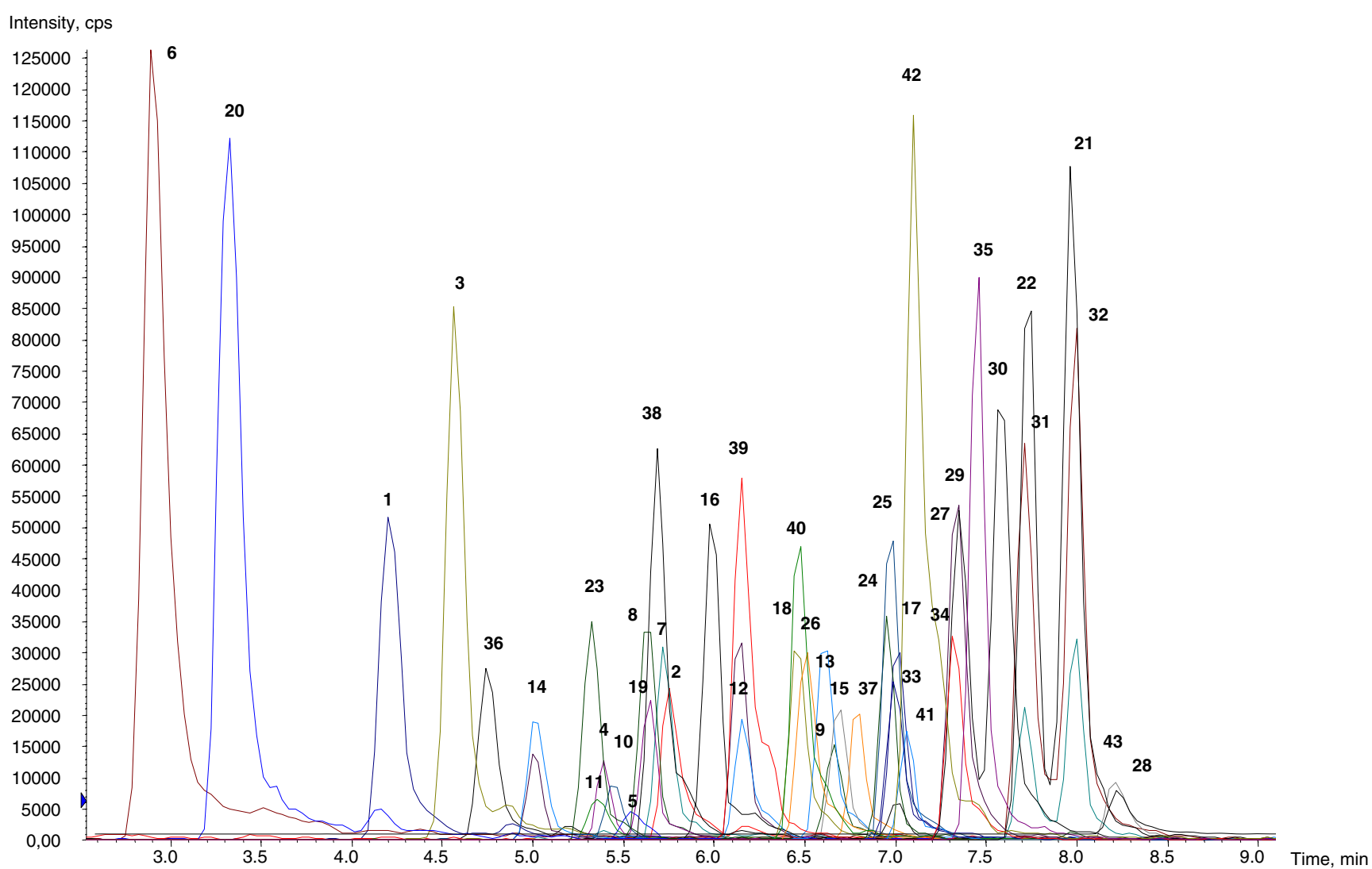

Fig. 2 Smoothed chromatogram of a serum sample spiked with all analytes in a concentration of $50 \mathrm{ng} / \mathrm{mL}$ and internal standard solution after solid-phase extraction. The numbers correspond to the numbers in Table 3 
Table 3 MRM transitions and corresponding collision energies, retention times, relative ion intensity of the first qualifier related to the target, corresponding internal standard and limits of detection of all substances

\begin{tabular}{|c|c|c|c|c|c|c|c|c|c|c|}
\hline No & Substance name & $\begin{array}{l}\text { Q1 } \\
\text { mass } \\
(\mathrm{amu})\end{array}$ & $\begin{array}{l}\text { Q3 } \\
\text { mass } \\
(\mathrm{amu})\end{array}$ & $\begin{array}{l}\text { Collision } \\
\text { energy } \\
(\mathrm{eV})\end{array}$ & $t_{\mathrm{R}}(\min )$ & $\begin{array}{l}\text { Relative ion } \\
\text { intensity } \\
\text { qualifier/target }\end{array}$ & $\begin{array}{l}\text { Internal } \\
\text { standard }\end{array}$ & $\begin{array}{l}\text { LOD } \\
(\mathrm{ng} / \mathrm{ml})\end{array}$ & $\begin{array}{l}S / N \text { ratio } \\
\text { quantifier }\end{array}$ & $\begin{array}{l}S / N \text { ratio } \\
\text { qualifier }\end{array}$ \\
\hline 1 & Cathinone & 150.0 & $\begin{array}{l}132.1 \\
117.1\end{array}$ & $\begin{array}{l}20 \\
35\end{array}$ & 4.21 & $70 \%$ & $d 5$-amphetamine & 2.5 & 22 & 28 \\
\hline 2 & Ethylamphetamine & 164.0 & $\begin{array}{r}91.0 \\
119.0\end{array}$ & $\begin{array}{l}35 \\
20\end{array}$ & 5.79 & $35 \%$ & $d 5$-MDMA & 2.5 & 17 & 5 \\
\hline 3 & Methcathinone & 164.0 & $\begin{array}{l}146.1 \\
131.1\end{array}$ & $\begin{array}{l}20 \\
20\end{array}$ & 4.57 & $41 \%$ & d5-amphetamine & 1.0 & 19 & 8 \\
\hline 4 & PMA & 166.0 & $\begin{array}{l}121.1 \\
149.1\end{array}$ & $\begin{array}{l}20 \\
20\end{array}$ & 5.37 & $86 \%$ & $d 5$-MDMA & 1.0 & 5 & 4 \\
\hline 5 & AMT & 175.0 & $\begin{array}{l}158.2 \\
143.1\end{array}$ & $\begin{array}{l}20 \\
35\end{array}$ & 5.57 & $33 \%$ & $d 5$-MDMA & 2.5 & 23 & 5 \\
\hline 6 & $\mathrm{BZP}$ & 177.0 & $\begin{array}{l}91.1 \\
65.1\end{array}$ & $\begin{array}{l}35 \\
50\end{array}$ & 2.91 & $12 \%$ & $d 5$-amphetamine & 5.0 & 56 & 5 \\
\hline 7 & PMMA & 180.0 & $\begin{array}{l}149.1 \\
121.1\end{array}$ & $\begin{array}{l}20 \\
35\end{array}$ & 5.74 & $81 \%$ & $d 5$-MDMA & 1.0 & 19 & 21 \\
\hline 8 & $2 \mathrm{C}-\mathrm{H}$ & 182.0 & $\begin{array}{l}165.2 \\
150.1 \\
135.2\end{array}$ & $\begin{array}{l}20 \\
20 \\
35\end{array}$ & 5.63 & $64 \%$ & $d 5$-MDMA & 1.0 & 40 & 6 \\
\hline 9 & 4-MTA & 182.0 & $\begin{array}{l}165.2 \\
117.1 \\
137.2\end{array}$ & $\begin{array}{l}20 \\
20 \\
35\end{array}$ & 6.66 & $57 \%$ & $d 4$-ketamine & 2.5 & 15 & 17 \\
\hline 10 & DMT & 189.0 & $\begin{array}{r}58.1 \\
144.1\end{array}$ & $\begin{array}{l}20 \\
20\end{array}$ & 5.46 & $85 \%$ & $d 5$-MDMA & 2.5 & 14 & 8 \\
\hline 11 & MeOPP & 193.0 & $\begin{array}{l}150.1 \\
119.0\end{array}$ & $\begin{array}{l}20 \\
35\end{array}$ & 5.36 & $61 \%$ & $d 5$-MDMA & 2.5 & 13 & 4 \\
\hline 12 & 2,5-DMA & 196.0 & $\begin{array}{l}151.1 \\
179.2 \\
121.1\end{array}$ & $\begin{array}{l}20 \\
20 \\
35\end{array}$ & 6.14 & $72 \%$ & $d 5$-MDEA & 5.0 & 15 & 12 \\
\hline 13 & $2 \mathrm{C}-\mathrm{D}$ & 196.0 & $\begin{array}{l}179.2 \\
149.1 \\
164.2\end{array}$ & $\begin{array}{l}20 \\
35 \\
20\end{array}$ & 6.63 & $24 \%$ & $d 4$-ketamine & 1.0 & 6 & 8 \\
\hline 14 & 3,4-DMA & 196.0 & $\begin{array}{l}179.1 \\
151.1 \\
107.1\end{array}$ & $\begin{array}{l}20 \\
20 \\
50\end{array}$ & 5.03 & $49 \%$ & $d 5$-amphetamine & 1.0 & 5 & 5 \\
\hline 15 & $\mathrm{mCPP}$ & 197.0 & $\begin{array}{l}154.1 \\
118.1\end{array}$ & $\begin{array}{l}50 \\
35\end{array}$ & 6.69 & $82 \%$ & DMPP (IS) & 1.0 & 14 & 4 \\
\hline 16 & MDDMA & 208.0 & $\begin{array}{l}163.2 \\
105.1\end{array}$ & $\begin{array}{l}20 \\
35\end{array}$ & 5.97 & $32 \%$ & $d 5$-MDEA & 1.0 & 7 & 9 \\
\hline 17 & DOM & 210.0 & $\begin{array}{l}193.2 \\
165.2\end{array}$ & $\begin{array}{l}20 \\
20\end{array}$ & 7.00 & $46 \%$ & $d 10$-fenfluramine & 1.0 & 10 & 14 \\
\hline 18 & MiPT & 217.0 & $\begin{array}{r}86.2 \\
144.2\end{array}$ & $\begin{array}{l}20 \\
35\end{array}$ & 6.46 & $71 \%$ & $d 4$-ketamine & 2.5 & 19 & 4 \\
\hline 19 & $5 \mathrm{MeO}-\mathrm{DMT}$ & 219.0 & $\begin{array}{r}174.2 \\
58.2\end{array}$ & $\begin{array}{l}20 \\
35\end{array}$ & 5.64 & $63 \%$ & $d 5$-MDMA & 1.0 & 8 & 6 \\
\hline 20 & MDBP & 221.0 & $\begin{array}{r}135.1 \\
76.9\end{array}$ & $\begin{array}{l}20 \\
50\end{array}$ & 3.33 & $11 \%$ & $d 5$-amphetamine & 5.0 & 49 & 4 \\
\hline 21 & $2 \mathrm{C}-\mathrm{P}$ & 224.0 & $\begin{array}{l}207.2 \\
192.2 \\
163.3\end{array}$ & $\begin{array}{l}20 \\
20 \\
35\end{array}$ & 8.00 & $33 \%$ & $d 5-\mathrm{PCP}$ & 1.0 & 18 & 57 \\
\hline 22 & DOET & 224.0 & $\begin{array}{l}207.1 \\
177.1\end{array}$ & $\begin{array}{l}20 \\
35\end{array}$ & 7.71 & $19 \%$ & $d 3$-cocaine & 5.0 & 209 & 17 \\
\hline
\end{tabular}


Table 3 (continued)

\begin{tabular}{|c|c|c|c|c|c|c|c|c|c|c|}
\hline No & Substance name & $\begin{array}{l}\text { Q1 } \\
\text { mass } \\
(\mathrm{amu})\end{array}$ & $\begin{array}{l}\text { Q3 } \\
\text { mass } \\
\text { (amu) }\end{array}$ & $\begin{array}{l}\text { Collision } \\
\text { energy } \\
(\mathrm{eV})\end{array}$ & $t_{\mathrm{R}}(\min )$ & $\begin{array}{l}\text { Relative ion } \\
\text { intensity } \\
\text { qualifier/target }\end{array}$ & $\begin{array}{l}\text { Internal } \\
\text { standard }\end{array}$ & $\begin{array}{l}\text { LOD } \\
(\mathrm{ng} / \mathrm{ml})\end{array}$ & $\begin{array}{l}S / N \text { ratio } \\
\text { quantifier }\end{array}$ & $\begin{array}{l}S / N \text { ratio } \\
\text { qualifier }\end{array}$ \\
\hline \multirow[t]{2}{*}{23} & 3,4,5-TMA & 226.0 & $\begin{array}{l}209.1 \\
181.1\end{array}$ & $\begin{array}{l}20 \\
20\end{array}$ & 5.32 & $10 \%$ & $d 5$-MDMA & 2.5 & 5 & 4 \\
\hline & & & 194.1 & 20 & & & & & & \\
\hline \multirow[t]{2}{*}{24} & TMA- 6 & 226.0 & $\begin{array}{l}209.2 \\
181.2\end{array}$ & $\begin{array}{l}20 \\
35\end{array}$ & 6.95 & $21 \%$ & $d 10$-fenfluramine & 2.5 & 15 & 7 \\
\hline & & & 121.2 & 35 & & & & & & \\
\hline 25 & TFMPP & 231.0 & $\begin{array}{l}188.2 \\
118.1\end{array}$ & $\begin{array}{l}35 \\
50\end{array}$ & 6.99 & $15 \%$ & DMPP (IS) & 5.0 & 141 & 28 \\
\hline 26 & ketamine & 238.0 & $\begin{array}{l}125.0 \\
220.2\end{array}$ & $\begin{array}{l}35 \\
20\end{array}$ & 6.51 & $83 \%$ & $d 4$-ketamine & 2.5 & 7 & 10 \\
\hline 27 & $2 \mathrm{C}-\mathrm{T}-2$ & 242.0 & $\begin{array}{l}225.2 \\
210.2\end{array}$ & $\begin{array}{l}20 \\
35\end{array}$ & 7.35 & $7 \%$ & $d 3$-cocaine & 1.0 & 19 & 8 \\
\hline 28 & phencyclidine & 244.0 & $\begin{array}{r}86.1 \\
159.1\end{array}$ & $\begin{array}{l}20 \\
50\end{array}$ & 8.23 & $90 \%$ & $d 5-\mathrm{PCP}$ & 2.5 & 9 & 14 \\
\hline \multirow[t]{2}{*}{29} & DiPT & 245.0 & $\begin{array}{l}114.2 \\
144.1\end{array}$ & $\begin{array}{l}20 \\
35\end{array}$ & 7.35 & $97 \%$ & $d 3$-cocaine & 1.0 & 42 & 15 \\
\hline & & & 117.1 & 50 & & & & & & \\
\hline \multirow[t]{2}{*}{30} & DPT & 245.0 & $\begin{array}{l}114.2 \\
144.2\end{array}$ & $\begin{array}{l}20 \\
35\end{array}$ & 7.60 & $49 \%$ & $d 3$-cocaine & 1.0 & 10 & 9 \\
\hline & & & 86.2 & 35 & & & & & & \\
\hline \multirow[t]{2}{*}{31} & $2 \mathrm{C}-\mathrm{T}-4$ & 256.0 & $\begin{array}{l}239.2 \\
167.2\end{array}$ & $\begin{array}{l}20 \\
35\end{array}$ & 7.72 & $29 \%$ & $d 3$-cocaine & 1.0 & 20 & 4 \\
\hline & & & 182.1 & 20 & & & & & & \\
\hline \multirow[t]{2}{*}{32} & $2 \mathrm{C}-\mathrm{T}-7$ & 256.0 & $\begin{array}{l}239.2 \\
167.2\end{array}$ & $\begin{array}{l}20 \\
35\end{array}$ & 7.98 & $9 \%$ & $d 5-\mathrm{PCP}$ & 1.0 & 11 & 8 \\
\hline & & & 182.1 & 35 & & & & & & \\
\hline 33 & $2 \mathrm{C}-\mathrm{B}$ & 260.0 & $\begin{array}{l}243.1 \\
228.1\end{array}$ & $\begin{array}{l}20 \\
35\end{array}$ & 7.01 & $27 \%$ & $d 10$-fenfluramine & 2.5 & 53 & 15 \\
\hline 34 & DOB & 274.0 & $\begin{array}{l}257.0 \\
229.1\end{array}$ & $\begin{array}{l}20 \\
20\end{array}$ & 7.34 & $45 \%$ & $d 3$-cocaine & 1.0 & 7 & 5 \\
\hline 35 & $2 \mathrm{C}-\mathrm{I}$ & 308.0 & $\begin{array}{l}291.0 \\
276.0\end{array}$ & $\begin{array}{l}20 \\
35\end{array}$ & 7.45 & $28 \%$ & $d 3$-cocaine & 1.0 & 55 & 12 \\
\hline 36 & d5-amphetamine & 141.0 & 93.1 & 20 & 4.74 & & & & & \\
\hline 37 & dimethylphenylpiperazine & 191.0 & 133.1 & 35 & 6.78 & & & & & \\
\hline 38 & d5-MDMA & 199.0 & 165.1 & 20 & 5.68 & & & & & \\
\hline 39 & d5-MDEA & 213.0 & 163.2 & 20 & 6.13 & & & & & \\
\hline 40 & d4-ketamine & 242.0 & 129.0 & 35 & 6.46 & & & & & \\
\hline 41 & d10-fenfluramine & 243.0 & 161.2 & 20 & 7.06 & & & & & \\
\hline 42 & d3-cocaine & 307.0 & 185.2 & 20 & 7.11 & & & & & \\
\hline 43 & d5-phencyclidine & 249.0 & 164.2 & 20 & 8.21 & & & & & \\
\hline
\end{tabular}

TFMPP 0.05 and $0.15 \mathrm{mg} / \mathrm{L}$ [5], for 2C-T-7 $0.057 \mathrm{mg} / \mathrm{L}$ (in heart blood) [29], for 4-MTA $4.6 \mathrm{mg} / \mathrm{L}$ (in femoral blood) [10], for DOB $0.019 \mathrm{mg} / \mathrm{L}$ [7], and for PMA $0.24-4.9 \mathrm{mg} / \mathrm{L}$ (six fatalities) [11]. In a nonfatal case of mCPP intoxication, the plasma concentration was $0.32 \mathrm{mg} / \mathrm{L}$ [3], in another case of a DOB ingestion, the concentration was $0.013 \mathrm{mg} / \mathrm{L}$, marginally lower than in the fatal case [7].
Regarding these values, it is safe to assume that serum concentrations will exceed the limits of detection.

Acknowledgments The authors like to thank Dr Sylvia Brunet Perez of the Landeskriminalamt Hamburg for providing compounds and the "Bund gegen Alkohol und Drogen im Straßenverkehr e.V." for financial support of the project. 


\section{References}

1. 2009, World Drug Report 2008, United Nations, Office on Drugs and Crime

2. 2009, Drogen- und Suchtbericht 2008, Bundesministerium für Gesundheit

3. Kovaleva J, Devuyst E, De Paepe P, Verstraete A (2008) Acute chlorophenylpiperazine overdose: a case report and review of the literature. Ther Drug Monit 30:394-398

4. Miyajima M, Matsumoto T, Ito S (2008) 2C-T-4 intoxication: acute psychosis caused by a designer drug. Psychiatry Clin Neurosci 62:243

5. Elliott S, Smith C (2008) Investigation of the first deaths in the United Kingdom involving the detection and quantitation of the piperazines BZP and 3-TFMPP. J Anal Toxicol 32:172-177

6. Tanaka E, Kamata T, Katagi M, Tsuchihashi H, Honda K (2006) A fatal poisoning with 5-methoxy- $N, N$-diisopropyltryptamine, Foxy. Forensic Sci Int 163:152-154

7. Balikova M (2005) Nonfatal and fatal DOB (2, 5-dimethoxy-4bromoamphetamine) overdose. Forensic Sci Int 153:85-91

8. Wilson JM, McGeorge F, Smolinske S, Meatherall R (2005) A foxy intoxication. Forensic Sci Int 148:31-36

9. Ling LH, Marchant C, Buckley NA, Prior M, Irvine RJ (2001) Poisoning with the recreational drug paramethoxyamphetamine ("death"). Med J Aust 174:453-455

10. Elliott SP (2000) Fatal poisoning with a new phenylethylamine: 4methylthioamphetamine (4-MTA). J Anal Toxicol 24:85-89

11. Felgate HE, Felgate PD, James RA, Sims DN, Vozzo DC (1998) Recent paramethoxyamphetamine deaths. J Anal Toxicol 22:169172

12. James RA, Dinan A (1998) Hyperpyrexia associated with fatal paramethoxyamphetamine (PMA) abuse. Med Sci Law 38:83-85

13. Boatto G, Nieddu M, Carta A, Pau A, Palomba M, Asproni B, Cerri R (2005) Determination of amphetamine-derived designer drugs in human urine by SPE extraction and capillary electrophoresis with mass spectrometry detection. J Chromatogr B Analyt Technol Biomed Life Sci 814:93-98

14. Boatto G, Nieddu M, Dessi G, Manconi P, Cerri R (2007) Determination of four thiophenethylamine designer drugs (2C-Tseries) in human plasma by capillary electrophoresis with mass spectrometry detection. J Chromatogr A 1159:198-202

15. Boatto G, Nieddu M, Pirisi MA, Dessi G (2007) Simultaneous determination of new thioamphetamine designer drugs in plasma by capillary electrophoresis coupled with mass spectrometry. Rapid Commun Mass Spectrom 21:3716-3720

16. Nieddu M, Boatto G, Dessi G (2007) Determination of 4-alkyl 2, 5 dimethoxy-amphetamine derivatives by capillary electrophoresis with mass spectrometry detection from urine samples. J Chromatogr B Analyt Technol Biomed Life Sci 852:578-581

17. Nieddu M, Boatto G, Carta A, Sanna A, Pisano M (2005) Simultaneous determination of ten amphetamine designer drugs in human whole blood by capillary electrophoresis with diode array detection. Biomed Chromatogr 19:737-742
18. Nieddu M, Boatto G, Pirisi MA, Azara E, Marchetti M (2008) LC-MS analysis of trimethoxyamphetamine designer drugs (TMA series) from urine samples. J Chromatogr B Analyt Technol Biomed Life Sci 867:126-130

19. Peters FT, Schaefer S, Staack RF, Kraemer T, Maurer HH (2003) Screening for and validated quantification of amphetamines and of amphetamine- and piperazine-derived designer drugs in human blood plasma by gas chromatography/mass spectrometry. J Mass Spectrom 38:659-676

20. Pichini S, Pujadas M, Marchei E, Pellegrini M, Fiz J, Pacifici R, Zuccaro P, Farre M, de la Torre R (2008) Liquid chromatographyatmospheric pressure ionization electrospray mass spectrometry determination of "hallucinogenic designer drugs" in urine of consumers. J Pharm Biomed Anal 47:335-342

21. Nordgren HK, Holmgren P, Liljeberg P, Eriksson N, Beck O (2005) Application of direct urine LC-MS-MS analysis for screening of novel substances in drug abusers. J Anal Toxicol 29:234-239

22. Vorce SP, Sklerov JH (2004) A general screening and confirmation approach to the analysis of designer tryptamines and phenethylamines in blood and urine using GC-EI-MS and HPLC-electrospray-MS. J Anal Toxicol 28:407-410

23. Nordgren HK, Beck O (2004) Multicomponent screening for drugs of abuse: direct analysis of urine by LC-MS-MS. Ther Drug Monit 26:90-97

24. Ishida T, Kudo K, Inoue H, Tsuji A, Kojima T, Ikeda N (2006) Rapid screening for and simultaneous semiquantitative analysis of thirty abused drugs in human urine samples using gas chromatography-mass spectrometry. J Anal Toxicol 30:468477

25. Matuszewski BK, Constanzer ML, Chavez-Eng CM (2003) Strategies for the assessment of matrix effect in quantitative bioanalytical methods based on HPLC-MS/MS. Anal Chem 75:3019-3030

26. Dresen S, Kempf J, Weinmann W (2006) Electrospray-ionization MS/MS library of drugs as database for method development and drug identification. Forensic Sci Int 161:86-91

27. Weinmann W (2009) ChemicalSoft, designer drugs product ion spectra API 365 (2009), www.chemicalsoft.de/designerdrugs2009/ MSMS_API-DD-index.php

28. Commission E (2002) 2002/657/EC: Commission Decision of 12 August 2002 implementing Council Directive 96/23/EC concerning the performance of analytical methods and the interpretation of results

29. Curtis B, Kemp P, Harty L, Choi C, Christensen D (2003) Postmortem identification and quantitation of 2, 5-dimethoxy-4- $n$ propylthiophenethylamine using GC-MSD and GC-NPD. J Anal Toxicol 27:493-498

30. Habrdova V, Peters FT, Theobald DS, and Maurer HH (2005) Screening for and validated quantification of phenethylamine-type designer drugs and mescaline in human blood plasma by gas chromatography/mass spectrometry. J Mass Spectrom 40:785795 